\title{
Post IPO Withdrawal Outcomes ${ }^{+}$
}

\author{
Boeh, Kevin and Dunbar, Craig*
}

\begin{abstract}
$\underline{\text { Abstract }}$
We document capital market activities and corporate outcomes every (588) withdrawn U.S. IPO between 1999 and 2004. Thirteen percent of withdrawn issuers return for a successful IPO, 36\% raise capital privately, $42 \%$ merge or are acquired, and $11 \%$ file for bankruptcy. Aside from cases where issuers successfully return for an IPO, valuations from post-withdrawal events are significantly discounted relative to pre-withdrawal valuations. Rival firms react positively to the withdrawal of competitor IPOs, suggesting that these firms would have been viable threats had their IPOs been completed. Further the paucity of positive post-withdrawal outcomes suggests withdrawal is costly to these potential competitors. Given the superior outcomes of a matched set of IPO issuers that drastically cut offering prices to complete their IPOs, firms considering withdrawal would be well served to instead cut their IPO offering prices.
\end{abstract}

JEL Classification: G14; G24; G32

Keywords: IPO, Withdrawal, Private Placement, Merger, Valuation, Rivals

\footnotetext{
+ We thank Dan Bradley, Walid Busaba, Delroy Hunter, Michael King, Frank Li, Ninon Sutton, Alessandro Previtero, Jianping Qi and seminar participants at the University of South Florida and Western University for helpful comments.

* Pacific Lutheran University, School of Business, 12180 Park Ave. S., Tacoma, WA 98447. Ph: (253) 535-8722; email: boehkk@plu.edu (Boeh, corresponding author) and Ivey Business School, Western University, 1225 Western Road Rm. 2309, London, Ontario, N6G 0N1, Canada. Phone: (519) 6613716; Fax: (519) 661-4027; email: cdunbar@ivey.uwo.ca.
} 


\section{Introduction}

An initial public offering (IPO) is an important event in the life of a young and growing company. Proceeds from the offering provide capital to support growth and public trading gives liquidity to entrepreneurs. Approximately $20 \%$ of all companies in the U.S. that begin the formal IPO filing process by filing security registration documents with the Securities and Exchange Commission (SEC), however, do not complete the process and withdraw their offering from registration (see Dunbar, 1998, Busaba, Benveniste and Guo, 2001, Dunbar and Foerster, 2008, and Boeh and Southam, 2011, among others). In some years (e.g., 2001) the majority of IPOs filed with the SEC are withdrawn. An IPO withdrawal can be a positive event if the issuer cancels the IPO to pursue better options. It also create a 'lemons' problem (Akerlof, 1970), however, making it challenging for the issuer to fund operations and survive.

In spite of the importance of the decision to withdraw an IPO we know very little regarding what happens to issuers post-withdrawal and whether withdrawals are negative or positive events. Our research question concerns the implications for those firms that withdraw from the IPO process. Dunbar and Foerster (2008) find that approximately $10 \%$ of firms withdrawing an IPO are able to later return for a successful IPO. Lian and Wang (2012) find that approximately 9\% of firms withdrawing an IPO are acquired while Cooney, Moeller and Stegemoller (2009) find 19\% are acquired. For over 70\% of issuers withdrawing an IPO, what happens post-withdrawal is not known.

This study attempts to add to our understanding of the consequences of the choice to withdraw an IPO by more thoroughly tracking capital market and corporate outcomes for issuers. Specifically we track all issuers that withdraw an IPO between 1999 and 2004 and look for post-withdrawal capital market events including IPO refilings (as in Dunbar and Foerster, 2008), mergers or acquisitions (as in Lian and Wang, 2012, and Cooney, Moeller and Stegemoller, 2009), and private placements. In addition to capital market events we search for information on important corporate events. Specifically, we search for announcements of corporate bankruptcies.

We focus on the period from 1999 to 2004 for several reasons. First there was a large number of IPO filings in this period (1660) with a large number of withdrawals (588), giving our empirical analyses 
sufficient power. While larger samples are desirable, focusing on a relatively smaller sample reduces the potential errors that can occur given the significant time involved in manual searches required to identify capital market and corporate outcomes. Also, while chronologically short, the period contains significant extremes in IPO activity, allowing generalizability of results. Finally, by considering offerings from the early 2000s, we have sufficient chronological time to observe post-withdrawal outcomes.

Overall we are able to identify capital market and corporate outcomes for virtually all IPO filers that withdrew between 1999 and 2004. Consistent with Dunbar and Foerster (2008) we find that approximately $13 \%$ of withdrawn issuers are able to successfully return for an IPO. Approximately $11 \%$ of issuers formally declare bankruptcy post IPO withdrawal. Approximately $36 \%$ are able to raise equity privately post withdrawal and $42 \%$ either merge or are acquired. Interestingly, the prevalence of post withdrawal mergers and acquisitions is much greater than found by Lian and Wang (2012) and Cooney, Moeller and Stegemoller (2009), even with significant sample period overlap, highlighting the challenges involved in data collection. Approximately $30 \%$ of issuers return to private status with no postwithdrawal capital market (capital raising or merger and acquisition) activity and one third of those have stopped operations (without formal bankruptcy filings).

Withdrawal has an unambiguously negative effect on those firms declaring bankruptcy or having no post withdrawal corporate events (approximately 35\% of the sample). For the other $65 \%$ issuers, the impact of withdrawal is less clear. A firm may withdraw an IPO to pursue a private placement given better available terms. In this case, the outcome is positive. On the other hand, an issuer may be forced to accept very poor terms in a private placement in order to survive after being rejected in the public markets. Similarly, issuers may cancel an IPO to pursue a merger at more favorable terms (a positive outcome) with others being acquired at poor terms after being weakened by the IPO failure.

To gain more insight into whether post-withdrawal outcomes tend to be positive or negative for the $65 \%$ of issuers having post-withdrawal corporate events (private placement, successful IPO or merger/acquisition) we examine valuation ratios, defined as the valuation implied by the post-withdrawal event, where available, divided by the industry return adjusted valuation implied by initial IPO filing 
terms. Issuers that are able to return for a successful IPO realize mean valuation ratios above $1 \mathrm{x}$. The mean valuation ratio for issuers withdrawing an IPO to pursue a private placement equals $0.52 \mathrm{x}$ with only $9 \%$ having valuation ratios above $1 \mathrm{x}$. The mean valuation ratio for issuers withdrawing an IPO to pursue a merger or acquisition equals $0.81 \mathrm{x}$ with only $32 \%$ having valuation ratios above $1 \mathrm{x}$. Because some issuers have multiple post-withdrawal events, we also consider the valuation ratio for the first outcome post-withdrawal. Only $25 \%$ of issuers having post-withdrawal corporate events have an initial valuation ratio above $1 \mathrm{x}$. Considering those issuers that have no post-withdrawal outcomes or declare bankruptcy, our evidence indicates that only approximately $16 \%$ of firms have positive post-withdrawal outcomes.

While a valuation ratio below $1 \mathrm{x}$ is consistent with withdrawal being a negative outcome, it could also arise because the initial IPO filing terms were simply set too high. To put our evidence in context we examine valuation ratios for successful IPOs over the same period where the issuer cut the issue price at least $20 \%$ from the initial filing (other cutoffs are considered but the results are not materially affected). These issuers arguably set their initial filing prices too high and yet were not 'rejected' by the market and were able to complete their IPOs. For these issuers we define the valuation ratio as the valuation at the fifth year anniversary of the IPO or delisting date, whichever comes first, divided by the industry return adjusted valuation implied by the initial IPO filing terms. The average valuation ratio for these issuers is $1.14 \mathrm{x}$ with $36 \%$ having a valuation ratio above $1 \mathrm{x}$. Excluding firms that are dropped from an exchange or liquidated, the average valuation ratio is $1.33 \mathrm{x}$ with $42 \%$ having a ratio above $1 \mathrm{x}$. Firms that push forward with an IPO after cutting prices obtain more favorable valuation outcomes than those that withdraw, suggesting that withdrawal is a worse outcome than having cut price to complete the IPO.

Given variation in post-withdrawal outcomes and valuation ratios, we examine factors affecting outcomes and valuations. Independent variables in our analysis include commonly used proxies in the IPO withdrawal literature to capture ex ante firm valuation uncertainty, access to alternative sources of capital, issue certification, and market timing. Carter-Manaster ranking for the lead bank in the withdrawn IPO and venture capital backing have a significantly positive effect on the likelihood a withdrawing firm has a post-withdrawal capital market outcome (private placement, merger or successful 
IPO). For issuers having a post-withdrawal corporate event, there is a positive relationship between issuer revenue as well as number of underwriters and valuation ratios. More established firms having the backing of more banks are in a better position to have more positive events (from a valuation perspective) post withdrawal. We also find a negative relationship between valuation ratios and filing size as well as a high tech industry dummy variable. High tech issuers face greater lemons concerns post withdrawal leading to lower valuations. Issuers that attempt to raise more capital in the IPO also face worse fates (from a valuation perspective) in post-withdrawal events.

Overall, our evidence suggests that most firms face negative post-withdrawal fates. There are two alternative hypotheses to explain these negative outcomes. First, issuers withdrawing their IPO may simply have been poor quality firms detected through the IPO process. Alternatively, the withdrawal itself could create challenges for the firm. As noted previously, the withdrawal event can create a lemons problem as future capital providers question why the firm could not complete its IPO. We attempt to determine the relative importance of these explanations by examining the market reaction to IPO withdrawals for industry rivals (see Hsu, Reed and Rocholl, 2010). If poor quality firms attempt to go public but are 'screened' by the IPO process, the market reaction to the IPO withdrawal should be negligible. The poor quality firm would have been determined to not be a real threat so its IPO outcome would be inconsequential. If instead the withdrawal is believed to have hurt what would have been a viable newly public competitor, market valuations of industry rivals should increase. We find that IPO rival valuations increase around withdrawals consistent with the assertion that the failure of the IPO filer to attract public capital makes creates more favorable competitive conditions for existing public rivals. Interestingly, we only find a significantly positive rival reaction to withdrawal if the withdrawing firm does not have a post-withdrawal capital market event or (more significantly) if that event is at a discounted valuation. The market reaction to withdrawals by issuers able to return for capital market events at positive valuations relative to the initial IPO filing is insignificant, consistent with withdrawals not being costly for that subset of firms. 
The remainder of this paper is organized as follows. In Section 2 we summarize regulations as well as the existing literature on IPO withdrawals. In Section 3 we describe the data used in our empirical analyses. In Section 4 we report our empirical findings with respect to valuation ratios, the factors affecting post-withdrawal outcomes and valuations, and the market reaction to withdrawals for industry rivals. We conclude and offer implications in Section 5.

\section{IPO Withdrawals}

\subsection{SEC regulations}

The regulatory processes behind the issuance and withdrawal processes for IPOs are well defined by Securities Acts that date to the early 1930s. Succinctly, a firm legally begins an IPO process when it brings together its bankers, lawyers, and auditors in an organizational meeting. This team prepares the registration statement (prospectus) that is filed with the SEC. During this period, the advisors also conduct due diligence and (perhaps) audits. The SEC returns comments on the prospectus regarding its compliance with regulatory requirements. Typically, after several rounds of editing, the SEC finds the statement acceptable. At this point, the firm's bankers send "Red Herrings" (so named because certain items are printed in red ink until the statement is complete) to potential investors, and conduct a (roughly) two-week road-show in which the firm and its bankers visit dozens of large institutional investors in faceto-face meetings to market the deal. During marketing, there are daily updates between the managers and the bankers as to the ongoing market reaction to the deal. After the marketing process, the lead investment bank(s) consider the indicated interest in purchasing the stock, and set a price (the "pricing call"). Upon acceptance of this price, the firm is then locked into the deal, as is the underwriting bank which then "commits" to purchase the shares until they are sold (typically next day) after which trading begins. At any point during this process, until acceptance of the price offered in the pricing call, the firm may simply withdraw the IPO. The underwriter may also walk away, but is somewhat limited by the legal requirement to act in the best interest of its client. 
Withdrawing an offering is simple, but not costless. A firm files a Form RW withdrawal request with the SEC, and then waits a period of time to raise private capital or else is subject to the "integration" doctrine. Integration entails costs and legal complexities, including registration and ongoing reporting requirements. The waiting period was six months after SEC approval of the request, but became 30 days from filing of the request after the adoption of Rule 155 and the amendment to Rule 477, both effective March 7, 2001. To subsequently switch to a private offering, a firm files a Form D with the SEC within 15 days of selling stock privately. Some firms raise private capital without filing a Form D due to reliance on another offering rule (which is rare), or based on the sloppiness (intentional or not) of the firm or its lawyers. Before and after the Rule changes, regulations require that a Form RW state grounds for withdrawal that are consistent with the public interest and investor protection. If a firm plans to subsequently conduct a private offering in reliance on the new Rules, the firm must state so. While the intent of the Rule changes was to ease capital formation, we do not present this time indicator in the models as we find no change in disclosure, or the likelihood of withdrawal or outcomes studied here.

\subsection{Theories of IPO Withdrawal and Implications for Post Withdrawal Outcomes}

Theories about IPO withdrawal generally focus either "bad" or "good" firm withdrawals. A taxonomy of explanations is given in Figure 1. In theory, when the market's assessment (and offer) of value exceeds an issuer's reservation price, the IPO should be completed. However, in the IPO marketing process information revealed about bad issuers may lead investors to correctly conclude that these firms would not be viable as public companies and are thus rejected. Theories of good issuer withdrawals can be further broken down into whether the issuer intends to complete the IPO. As in Lian and Wang (2012), some may not genuinely intend to issue and instead use the IPO filing to increase bargaining power in a merger or acquisition by creating a viable alternative. Firms with an intent to issue withdraw because the price offered by the market is inferior to a reservation price or real alternative offer. This includes when the firm is irrationally undervalued because of market conditions (e.g., spillovers (Bradley and Yuan, 2013) or cascades (Welch, 1992)), because the firm cannot convince the market of its value, or because the issuer has an alternative offer presented and chooses instead to pursue it (e.g., Lian and Wang, 2012). 
Insert Figure 1 about here

Busaba (2006) extends Benveniste and Spindt's (1989) classic information acquisition theory to allow for the possibility of IPO withdrawal. He shows that the existence of an issuer reservation price affects the pricing and allocation equilibrium giving bankers more leverage in inducing truthful revelation of positive information from investors. The focus of the model is on the pricing and allocation equilibrium for IPOs that are completed. Busaba does not present a formal theory relating the consequences of withdrawal to the optimal establishment of a reservation value. Welch (1992) also develops a formal model showing how information cascades can affect IPO pricing and success. He shows how early demand for an IPO can affect later demand, given information asymmetries, resulting in demand cascades. Welch notes that if issuers have a reservation value, negative information cascades would result in IPO withdrawals. Like Busaba (2006), Welch does not develop a formal theory relating the consequences of withdrawal to the optimal establishment of a reservation value.

Other studies develop less mathematically formal explanations for IPO withdrawals to motivate empirical analyses. Busaba, Benveniste and Guo (2001) argue that the decision to withdraw an IPO should depend on the relation between issuers' reservation values for the offering and investor valuations. They propose a number of factors that should affect issuers' reservation values including the existence of alternative sources of capital, the risk aversion of the issuer and the magnitude of the negative signal of a withdrawal. Issuers with alternative sources of capital are more likely to establish higher reservation prices (as the consequences of withdrawal are less negative) and, all else equal, are more likely to withdraw their IPO. More risk-averse issuers are likely to establish a lower reservation price (given more negative consequences to withdrawing), reducing the likelihood of withdrawal. Finally, withdrawals from issuers with greater ex ante uncertainty about valuation with less potential transparency with respect to their reason for withdrawal are likely to create more negative signals. These issuers, therefore, should establish a lower reservation price reducing the probability of withdrawal. 
Busaba, Benveniste and Guo also propose a number of factors that should affect investor valuations including the ex-ante firm valuation uncertainty and market valuation movements. Information learned during bookbuilding should have a larger impact on investor valuations when ex ante uncertainty is high. The likelihood of withdrawal, therefore, should be higher for these issuers. Similarly withdrawal should be more likely after negative market or industry movements. Because these factors are also likely to impact issuer reservation values, net effects are difficult to predict. Busaba, Benveniste and Guo therefore simply use this list of factors to identify proxies to include in withdrawal choice regressions and then let the data decide what effects dominate.

In their empirical analysis of IPO withdrawals, Dunbar and Foerster (2008) extend Busaba, Benveniste and Guo by considering additional factors that affect either investor valuations or issuer reservation values. They note that issuers can affect ex ante valuation uncertainty in two ways. First they can use intermediaries that use their reputations to certify value, reducing ex ante uncertainty. Second, they can time their issue to follow similar issuers. Information learned by investors from those other issues should spill over, reducing ex ante uncertainty.

While the existing studies have focused on the choice to withdrawal, they can be extended to make predictions regarding the factors affecting post-withdrawal fates. IPOs withdrawn by issuers with greater ex ante valuation uncertainty are more likely to face a 'lemons' problem (Akerlof, 1970). Post withdrawal, potential investors will find it harder to determine whether the issuer withdrew voluntarily (e.g., due to poor market conditions) or was 'rejected' by the market making it more difficult for those issuers to access capital at reasonable terms and survive. IPOs withdrawn by issuers with existing alternative capital sources (debt or venture capital financing) are likely to face more positive post withdrawal fates for two reasons. First, given better information about the issuer, those capital providers are less likely to be affected by lemons concerns. Second, these issuers already have a more diverse set of investors to turn to for financing. Issuers having greater 'certification' in the IPO attempt (e.g., have venture capital backing, or taken public by more reputable banks) are less likely to face as serious lemons concerns, improving post withdrawal outcomes. Similarly, issuers withdrawing during more active 
markets should face less of a lemons problem given the significant information arising during these active periods. Finally, firms should face more positive post-withdrawal fates when market conditions improve (e.g., when industry valuations increase for public firms).

\section{Data}

The core dataset of IPOs used in this study is from the Thomson Financial Securities Data Corporation (TFSDC) New Issues database. Our study concerns the outcomes of firm-commitment IPO filers during the 1999 and 2004 time period. These outcomes are for firms that were either on file as of January 1, 1999, or that filed with the SEC thereafter. This required that we obtain all filings leading up to and onfile with the SEC as of January 1, 1999, as well as all filings thereafter. We focus on domestic U.S. filers and eliminate foreign filers and American Depositary Receipts or Global Depositary Receipts because of differences in information asymmetry and local bankruptcy laws. Because they offer different protections and risks and are often sold to different investor groups, we eliminate unit offerings, closed-end funds, enhanced income and income deposit securities, limited liability, limited partner, shares of beneficial interest and trusts. Financial firms are included, but savings \& loan/bank trust conversions are excluded because these deals directly convert to public status without a normal IPO process. Due to information asymmetry differences, we also eliminate firms with existing disclosure, whether through a parent (e.g., sub-IPOs, spin-offs, tracking stock) or directly (e.g., filers with existing publicly held debt, and thus are SEC reporting firms). The result is a sample of 1,660 offerings that had outcomes during the 1999 to 2004 period, of which 588 deals were withdrawn. Because the TFSDC dataset is incomplete (especially for withdrawn deals) we hand-collect missing data from SEC filings, and in the process we correct or verify much of the rest of the TFSDC data.

We focus our outcomes data collection on the five year period following the withdrawal (i.e., through 2004 for 1999 withdrawals, through 2009 for 2004 withdrawals) to ensure a consistent timeframe for post-withdrawal activities to occur. Merger and acquisition and private placement data are obtained from SEC filings, TFSDC Private Issues and Mergers \& Acquisitions databases, from firm and investor press 
releases, and news sources (e.g., Reuters). Data on bankruptcy filings are obtained from court records using Lexis-Nexis and verified by news sources and firm websites. Often, an individual data source is insufficient and/or inaccurate, and so we use multiple sources for each data item and where conflicting data cannot be resolved, we use phone calls to firm personnel, bankers or lawyers listed in the prospectus to verify data. While laborious, the phone calls provide resolution to outcome facts (e.g., did the firm file for bankruptcy? Is the firm still alive? Was it sold?). These direct investigations are particularly helpful when filers withdraw and dissolve and/or change their corporate names. The redundant and in-depth data checking for every outcome $(\mathrm{n}=588)$ adds assurance regarding data reliability.

As noted, the sample consists of 1,660 IPO filings. The period begins with 141 deals on file as of December 31, 1998 after which 1,580 deals are filed, 1,072 IPOs are completed, and 588 withdrawals occur, leaving 61 deals on file as of December 31, 2004. Table 1 provides a breakdown of filing, completion, and withdrawal activity by quarter during the period.

\section{Insert Table 1 about here}

Table 1 includes ratios to describe the state of the IPO markets. The Filing:Pipeline ratio is the relative number of firms choosing to seek capital compared to the number in the process of seeking capital. These additions to the pipeline range from .09x to $1.65 \mathrm{x}$ (9\% to $165 \%)$. The next ratio is the IPO:Pipeline and measures the percentage of IPO pipeline that is cleared each quarter. These are capital seekers that are "successful", and ranges from .04x to $.84 x$. The Withdrawal:Pipeline ratio measures IPO pipeline clearing due to capital seekers that withdraw. This "failure" ratio ranges from $.03 x$ to $.42 x$. The final column is the percentage of outcomes that are withdrawals, ranging from $3 \%$ to $90 \%$. All four measures indicate the health of the IPO markets and all show variation. While 1999-2000 years are archetypes for "hot" markets, these ratios give a more complete picture of what is "hot" and "cold". For example, a comparison of the peak of the dot com IPO bubble (NASDAQ peaked in March, 2000) to Q1 2004 shows an IPO market this is "hotter" with respect to attracting capital (Filings:Pipeline of 1.6x vs. 1.51x, 
IPOs:Pipeline of .73x vs. .62x, WD:Pipeline of .03x vs. .13x, and WD as a percentage of outcomes of $3 \%$ vs. 17\%), although the volume of completed IPOs is lower. Importantly, the measures show the importance of controlling for IPO market conditions (we do) and offer evidence that our sample includes a wide range of market conditions suggesting external validity.

SEC regulations require filing of a Form RW when a firm wishes to withdraw its IPO registration statement and that it state grounds for withdrawal that is (are) consistent with the public interest and investor protection. However, being truthful in this disclosure may cause harm (a self-declared "lemon"). These statements are publicly available and are signals. Despite regulations requiring valid disclosure, a firm with a negative reason for withdrawal has conflicting incentives regarding disclosure.

Table 2 shows the stated reasons for withdrawal in every Form RW filed with the SEC for our sample. Categorized as either informative or uninformative, few firms give informative reasons for withdrawal. Just $3(.51 \%)$ firms report the desire to switch to a private offering and $46(7.82 \%)$ suggest a merger (far lower than the rate of actual private offerings or mergers noted previously). While the eventual outcome of the firm is not known with certainty at withdrawal, only $9 \%$ of the stated reasons for withdrawal might be construed as negative suggesting firms are likely being economical with the truth.

Insert Table 2 about here

In addition to the data sources noted above, we obtain data from CRSP (e.g., shares data after the IPO) and Compustat (e.g., pre-IPO debt and revenue). The sources of data for all independent variables used later in the study are detailed in the Appendix along with summary statistics.

\section{IPO Withdrawals and Post-Withdrawal Outcomes - Empirical Evidence}

\subsection{Post- Withdrawal Outcomes}

The focus of this study is on the capital market and corporate outcomes for the 588 IPO filers that withdraw their IPOs. Issuers are categorized as having a bankruptcy if the firm files for either Chapter 7 
or 11 bankruptcy protection in a U.S. court filing. Issuers are categorized as having a private placement if the firm raises capital of any form (equity, debt, and hybrid instruments, but limited to non-majority investments) from investors outside the firm (thus excluding internally raised funds). Issuers are categorized has having a merger or acquisition where there is an outright purchase, a majority ( $\geq 50 \%)$ investment in the issuing firm, or a merger in which the withdrawn firm retains a minority position in the new entity $(<50 \%)$. We do not categorize issuers as having merger or acquisition if the withdrawn firm is the purchaser. Finally, issuers are categorized as re-filing for an IPO if the issuer returns to the market and files anew for an IPO post withdrawal.

Table 3 presents the actual occurrences of private placements, re-filing for a subsequent attempt at IPO, bankruptcy, and merger or acquisition, and all combinations of these events for the entire sample of 588 withdrawals. Nearly $37 \%$ of the firms (215 in total) in the sample were able to subsequently raise private capital. Of the $74(12.59 \%)$ firms that re-filed for another IPO, 45 were successful. Sixty-six issuers that withdraw their IPO ultimately file for bankruptcy. Finally, 250 issuers (approximately 43\%) were involved in a merger or acquisition. As noted previously, this is a much higher rate of post withdrawal merger/acquisition activity than reported by Lian and Wang (2012) or Cooney, Moeller and Stegemoller (2009). Of the 250 issuers involved in merger/acquisition activity, 68 complete the merger/acquisition before the withdrawal of the IPO (as noted by Lian and Wang these issuers are likely to have used the IPO filing to improve bargaining in an ongoing merger/acquisition negotiation). Interestingly, there are many cases where issuers are involved in multiple capital market events post withdrawal.

Insert Table 3 about here

\subsection{Implied Valuation Evidence}

Data are available in some cases to compare valuations implied from the initial IPO filing to postwithdrawal outcomes. Of the 588 withdrawn IPOs, 314 provide sufficient data to determine a firm 
valuation, computed as the number of shares to be outstanding after the offering multiplied by the average of the high and low filing prices (the other 274 were withdrawn before the issuer established the number of shares to be offered along with a price range). These valuations can be compared to those implied in post-withdrawal events, where disclosed. Of the 212 firms having private placements post-withdrawal, 89 disclose information so that an implied firm value can be determined (i.e., where dollars raised and share of equity obtained are disclosed). Of the 234 firms involved in a merger or acquisition 148 disclose terms sufficient to compute an implied firm value (i.e., where consideration paid and fraction of firm acquired are disclosed). Finally in all 45 cases where a firm re-files and completes its IPO it is possible to compute an implied firm value.

Table 4 reports summary statistics on implied firm values. The mean firm value implied in 314 initial filings is $\$ 309$ million (median of $\$ 229$ million). The mean firm value implied in the 89 private placements is $\$ 200$ million (median of $\$ 127$ million). For firms having multiple private placements we use the first post-withdrawal private placement where data are available to compute implied value. The mean firm value implied in the 148 mergers or acquisitions is $\$ 333$ million (median of $\$ 134$ million). Finally the mean firm value implied in the 45 successfully refiled IPOs is $\$ 519$ million (median of $\$ 248$ million). Because disclosure of valuation terms is voluntary, self-selection becomes an issue as we consider extrapolating this evidence. We test for self-selection by comparing mean and median values of all independent variables considered in previous analyses for different subsamples (e.g., 314 withdrawing firms with valuation data compared to the other 274 filers; 89 firms disclosing valuation data in private placements compared to the 123 that do not; etc.). Overall we find few significant differences between the various subsamples suggesting that self-selection bias should not be a significant concern.

\section{Insert Table 4 about here}

The sample averages noted above are not directly comparable, however, given different compositions of firms. To get better comparisons, we look at firms for which initial IPO filings as well as follow on 
events have valuation information. For these firms we can then compute valuation ratios, defined as the value implied in the follow on event divided by the value implied in the initial IPO filing. ${ }^{1}$ To account for timing differences, we scale the valuation implied in the IPO filing by the cumulative return on an index of firms in the issuer's industry (using the Fama-French, 1997, 17 industry classification system; see French's website http://mba.tuck.dartmouth.edu/pages/faculty/ken.french/data_library.html for details). ${ }^{2}$ Summary statistics on valuation ratios are provided in Table 4 . Of the 212 issuers having private placements post-IPO withdrawal, 47 have sufficient data to compute a valuation ratio. The mean valuation ratio is $0.52 \mathrm{x}$ with median of $0.40 \mathrm{x}$ (both are statistically significantly less than 1 ). Only $9 \%$ have valuation ratios above 1x. Most firms pursue private placements at deep discounts.

Of the 234 issuers having mergers or acquisitions after IPO withdrawal, 68 have sufficient data to compute a valuation ratio. The mean valuation ratio is $0.81 \mathrm{x}$ with a median of $0.67 \mathrm{x}$ (both are statistically significantly less than 1x). Firms pursuing mergers/acquisitions post IPO withdrawal face similar discounting (although to a lesser degree) as issuers pursuing private placements. Lian and Wang (2012) argue that the timing of the merger/acquisitions should affect the valuation ratio. Some mergers/acquisitions occur before the IPO is formally withdrawn with others occurring later. Lian and Wang argue that some firms begin the IPO process simply to improve their bargaining position in merger talks. Of the 68 firms in our sample with sufficient data to compute valuation ratios, 19 merge or are acquired before the withdrawal date with 49 occurring after. The mean valuation ratio for the first group is $1.09 \mathrm{x}$ and the valuation ratio in the second is $0.70 \mathrm{x}$. While the difference in valuation ratios is not statistically significant, this evidence is consistent with the findings of Lian and Wang.

Of the 45 withdrawn issuers that return for a successful IPO, 22 have sufficient data to compute valuation ratios. The mean valuation ratio is $1.22 \mathrm{x}$ with median of $0.81 \mathrm{x}$ (neither is statistically

\footnotetext{
${ }^{1}$ Cooney, Moeller, and Stegemoller (2010) use a similar measure to examine the valuation change between initial filing and acquisition. They then use these valuation changes to explain bidder returns in acquisitions.

${ }^{2}$ We consider other benchmarks including the Fama-French 48 industry classification system. Our results are qualitatively unaffected.
} 
significantly different from 1x). Only firms able to successfully return to the IPO market do not appear face significant discounting in firm valuation.

As noted previously, some issuers have multiple capital market events post-withdrawal. To get a better sense of the valuation impact of withdrawal, we combine events and focus on the first to occur post-withdrawal. Of the 368 firms having some post-withdrawal capital market event, 113 have sufficient data to compute valuation ratios. The mean valuation ratio is $0.78 \mathrm{x}$ and the median is $0.6 \mathrm{x}$ (both are significantly less than $1 \mathrm{x}$ ). Only $25 \%$ of firms have a valuation ratio above $1 \mathrm{x}$ with their first postwithdrawal capital market event. While some firms have positive post withdrawal outcomes from a valuation perspective, the vast majority do not.

While this evidence is consistent with IPO withdrawals being a negative event for most issuers ${ }^{3}$, it could also simply reflect the initial IPO terms being set unrealistically high. To put this evidence in context we attempt to identify a matched sample of successful IPOs of issuers that make significant negative adjustments to IPO prices (and therefore firm valuation) through the IPO process. Using the argument that the IPO of any firm that is viable as a public entity should be issuable at a sufficiently low price. We focus on a sample of issuers where the final IPO price is at least $20 \%$ below the average of the high and low price indicated in the initial filing. We focus on $20 \%$ price adjustments in part because SEC rules indicate that $20 \%$ price adjustments are sufficiently 'material' to require amendments be filed prior to approval (see Bradley and Jordan, 2002). Other cutoffs are considered in our empirical analyses, however, and results are not qualitatively affected (statistical significance of findings declines with higher percentage cutoffs, as sample sizes are reduced resulting in lower power).

For issuers reducing prices by at least $20 \%$ we compute valuation ratios in a manner comparable to those for withdrawn issuers. We first compute the market capitalization for each firm on the fifth anniversary of its IPO using date from CRSP (closing price multiplied by shares outstanding). In some

\footnotetext{
${ }^{3}$ The valuation ratio probably understates the negative impact of withdrawal as we only look at firms that have some post-withdrawal capital market event. These are likely to be the least impacted firms by the withdrawal of an IPO. We also only are able to observe valuations when voluntarily provided and this also most likely creates a bias against finding negative outcomes.
} 
cases issuers are delisted prior to the fifth anniversary (e.g., the firm merges, is acquired, or is liquidated, and is dropped from an exchange). In these cases we compute the market capitalization on the delisting date. We then compute the valuation implied in the IPO filing (average of initial filing price range multiplied by the shares to be outstanding after the IPO), scaled by the cumulative return on an index of firms in the issuer's industry (using the Fama-French, 1997, 17 industry classification system). The valuation ratio is then defined as the post-IPO valuation (fifth year post-IPO or at delisting date) divided by the industry-adjusted valuation implied at initial IPO filing. By using the valuation at initial filing as the denominator, this definition is comparable to what we use for withdrawn IPOs. The ratio could be less than $1 \mathrm{x}$ because long run performance is poor or because the initial filing price was set too high.

Evidence on valuation ratios for successful IPOs is provided in Table 5. Over this time period there were 200 IPOs making a price adjustment of greater than $-20 \%$. The mean valuation ratio is $1.14 \mathrm{x}$, which is not statistically significantly different from $1 \mathrm{x}$. This suggests that average long run performance for these issuers is not negative, even with the initial over pricing implied at filing. The median valuation ratio is $0.50 \mathrm{x}$ and significantly less than one, however, indicating that the data are highly skewed. Only $36 \%$ have valuation ratios above $1 \mathrm{x}$. This proportion is much greater than the $16 \%$ observed for withdrawn issuers, however. Issuers that move ahead with an IPO after making large negative price adjustments appear to fare better than those that choose to withdraw. This is consistent with withdrawal being a negative event for most issuers.

Insert Table 5 about here

In the second column of Table 5 we examine valuation ratios for issuers that are acquired post IPO. The mean valuation ratio is $1.01 \mathrm{x}$ and the median is $0.66 \mathrm{x}$, neither being significantly different from $1 \mathrm{x}$. Issuers contemplating going public to set up an eventual acquisition have better fates, from a valuation perspective, by proceeding with the IPO rather than canceling. In the third column we consider IPOs that are dropped from an exchange or liquidated. Not surprisingly, valuation ratios are extremely low (mean 
of $0.05 \mathrm{x}$ and median of $0.02 \mathrm{x}$ ). In the final column of Table 6 we consider only IPOs that are not dropped or liquidated. This sample is arguably most comparable to the full sample of withdrawn IPOs considered in Table 4. The mean valuation for this sample is significantly greater than $1 \mathrm{x}(1.33 \mathrm{x})$ although the median is significantly less than $1 \mathrm{x}(0.70 \mathrm{x})$. Approximately $42 \%$ of these issuers have valuation ratios in excess of $1 \mathrm{x}$, much higher than the $25 \%$ observed for withdrawn issuers.

Overall, this evidence is consistent with withdrawal being a negative event for most firms. Firms that choose the cut their issue price and proceed with an IPO fare better, from a valuation perspective, than those that cancel.

\subsection{Factors Affecting Post-Withdrawal Outcomes}

Because withdrawal appears to be a negative event for most issuers we next explore factors affecting post-withdrawal outcomes and valuations. As discussed previously, post-withdrawal outcomes should be related to ex ante valuation uncertainty, issue certification, access to alternative sources of capital, market timing and market conditions. Building on existing empirical research on IPO withdrawals, we organize independent variables in four groups. Sources of data and summary statistics for all independent variables are provided in the Appendix. Our first two variables are commonly used to capture issue characteristics: log of filing size and use of proceeds to repay debt. Filing size is the number of shares to be sold in the IPO (excluding overallotments) multiplied by the average of the high and low filing price, stated in millions of dollars. We use the first pricing and share data established by the issuer in either the initial registration document or subsequent amendment. For many withdrawn offerings an initial filing price range is never established. In these cases we use the size of the offering indicated in the initial registration document established by the issuer in order to determine registration fees. The $\mathbf{l o g}$ of filing size is then defined as the natural logarithm of the filing size. This variable is typically included as a proxy for ex ante firm value uncertainty. Use of proceeds to repay debt is a dummy variable taking the value 1 if one of the stated uses of proceeds in the issuer's registration document is to repay debt. This variable is included to capture an issuer's access to alternative sources of capital. 
The next three independent variables we consider capture issuer characteristics: log of revenue, high tech industry dummy, and firm age. We first measure the last-twelve-month revenue of the issuer, in millions of dollars. The log of revenue is the natural logarithm of one plus last-twelve-month revenue. This variable is a commonly used proxy for ex ante valuation uncertainty. Issuers with greater existing revenue also have greater access to alternative (internally generated) capital. Following Dunbar and Foerster (2008) high tech industry dummy takes the value 1 if the issuer is in Fama and French (1997) industries 35, 36 or 37 (business services, chips, or computers) based on their primary SIC code. High tech firms are likely to have greater ex ante valuation uncertainty. Also, given fewer tangible assets, the negative signal from withdrawal is likely to be more significant for these firms. Firm age (here, at the outcome date) is a common measure of ex ante valuation uncertainty (see Chemmanur and Fulghieri, 1999).

The next three independent variables capture intermediary characteristics: Carter-Manaster ranking, number of underwriters, and venture capital dummy. Carter-Manaster ranking is obtained from Carter and Manaster (1990) as updated by Carter, Dark, and Singh (1998) and more recently by Loughran and Ritter (2004). These rankings are on a 0 to 9 scale, with 9 being the most reputable underwriter. Offerings brought forward by banks with higher Carter-Manaster ranks have greater certification. The number of underwriters is a count of the number of lead underwriters for the IPO (see Hu and Ritter, 2007). Corwin and Schultz (2005) argue that IPOs with more underwriters access more information through bookbuilding, increasing the likelihood of receiving both positive and negative information. Finally venture capital dummy takes the value 1 if the issuer received venture capital financing prior to the IPO filing. Firms with venture capital backing have greater certification and presumably have greater access to alternative sources of capital. Also, Gompers (1996) notes venture capitalists have an incentive to lobby hard for IPO completion in order to monetize their stakes.

Our next two variables capture IPO market conditions at the time of initial filing: hot IPO market dummy and cold IPO market dummy. Following Helwege and Liang (2004), a hot period occurs when equity volume exceeds the upper quartile for three consecutive months; a cold period occurs when equity 
volume falls below the lower third for three months. Information spillovers and information asymmetries are likely to be very different in hot and cold markets. Of the 1660 filings, 650 outcomes occur in hot markets with 252 occurring in cold markets.

Our final two variables capture market conditions after IPO filing: days from filing to IPO or withdrawal, and average daily industry return from filing to IPO or withdrawal. With longer filing periods, the chance increases that negative information will arise, increasing the overall likelihood of withdrawal. Issuers requiring multiple amendments, perhaps due to disclosure problems, are also more likely to have longer registration periods. To the extent these challenges are not observable to the market, lemons problems likely increase with the length of the registration period. The average daily industry post-filing return should have a positive effect on investor valuations.

The estimated Probit model of post-withdrawal events is reported in the first column of Table 6. In this model the dependent variable takes the value 1 if the issuer has some post-withdrawal outcome (merger, private placement or returns for an $\mathrm{IPO}^{4}$ ). We report model coefficient estimates and associated t-statistics. We also report the marginal effect for each variable which captures the change in the probability of having a post-withdrawal outcome given a one standard deviation change in the independent variable. The only significant variables in this regression are Carter-Manaster ranking and the Venture Capital Dummy, both having a positive impact on post withdrawal outcomes. A one standard deviation increase in the Carter-Manaster ranking results in an $8.3 \%$ increase the probability of having a post-withdrawal corporate event. This is consistent with certification effects having a positive effect on outcomes. The presence of Venture Capital backing increases the probability of a post-withdrawal event by $24 \%$. The existence of venture capital backing provides both certification and a potential source for follow-on financing.

Insert Table 6 about here

\footnotetext{
${ }^{4}$ Given $n=588$, firms without such an event either returned to private status $(n=180)$ or had a bankruptcy without any other event $(n=20)$, thus 388 had an event (=1 in the probit model) while $200(=0)$ did not.
} 
In the second model of Table 6 the dependent variable takes the value 1 if the valuation ratio exceeds one, and zero otherwise. We consider other valuation ratio cutoffs in estimating this Probit model but results are qualitatively unaffected. We find that log of filing size and high tech industry dummy have a significantly negative effect on the likelihood of having a positive post-withdrawal event valuation. High tech issuers are likely to face greater lemons concerns post withdrawal. It may be surprising that larger issues face more negative valuation effects as firms with larger initial filings are likely to be more established. The evidence is consistent with issuers creating long-term problems (reputation or otherwise) by having an irrationally high reservation price. Finally, the log of revenue and the number of underwriters have significantly positive effects on valuation ratios. Firms with greater revenues backed by more underwriters are likely to be more established. The most economically significant variables in this model are the log of filing size, log of revenue and number of underwriters. A one standard deviation change in these variables results in an approximately $15 \%$ change in the probability of having a positive valuation (conditional on having a post withdrawal event).

\subsection{Market Reaction to Withdrawals for Rival firms}

As noted above, only approximately $16 \%$ of withdrawn IPO issuers have positive post-withdrawal (valuation) fates. There are two alternative explanations for this outcome. First, issuers withdrawing an IPO may simply have been poor quality firms detected through the IPO process. Alternatively, many withdrawing firms may be of good quality but the withdrawal event creates challenges. There are direct costs to issuers of withdrawn IPOs as intermediary (investment bank, lawyers, etc.) expenses must still be covered. As noted previously, withdrawal also can create a lemons problem for the issuer. When the post-withdrawal firm approaches providers of capital or acquisition targets, there may be residual doubt as to why the IPO was canceled. In this section we attempt to determine the relative importance of these explanations for poor post withdrawal outcomes.

Specifically, we examine the market reaction to the announcement of an IPO withdrawal among industry peers. Hsu, Reed and Rocholl (2010) examine the reaction of peers to IPO announcements and 
completions or withdrawals. They argue there are competitive benefits to being public and that the addition of another IPO-funded public competitor destroys incumbents' value. When an IPO is withdrawn, Hsu, Reed and Rocholl (2010) argue this should be good news for publicly traded rivals. We argue that the stock price reaction to an IPO withdrawal among industry peers should depend on the perceived quality of the potential issuer. If investors believe through the roadshow process that the new issuer is not a credible competitor, there should be little market reaction to withdrawal for industry rivals, in part because the withdrawal itself would not be a surprise. If the new issuer was viewed to be a credible competitor and, therefore, the withdrawal is a surprise, the market reaction for rivals could again be insignificant if the withdrawal event was deemed to not cause harm for the issuer. If, however, the withdrawal is a surprise and also deemed costly, the market reaction to the withdrawal for competitors should be positive.

To test the market reaction for peers to an IPO withdrawal, we follow Hsu, Reed and Rocholl (2010) and only consider "clean" withdrawal events. We exclude cases where there were other industry IPOs filed in the four months preceding withdrawal and postponed between the withdrawal date and its four month anniversary. In doing so, we attempt to focus on withdrawal events where the market reaction cannot partly reflect views regarding other possible public competitors. ${ }^{5}$ Following Bradley and Yuan (2013), who similarly examine peer reaction to seasoned equity offerings, we define industry rivals using four-digit SIC codes. Overall there are 220 withdrawn IPOs that meet our screening requirement. ${ }^{6}$ For each withdrawn IPO we identify all publicly traded rivals on CRSP where daily stock prices are available for at least one year pre-withdrawal. For each rival we estimate the following market model over event days -250 to -11 relative to IPO withdrawal:

$$
R_{i t}=\alpha_{i}+\beta R_{m t}+\varepsilon_{i}
$$

\footnotetext{
${ }^{5}$ Hsu, Reed and Rocholl (2010) use an alternative approach which considers only IPO filings not preceded or followed by a larger IPO in the same industry in the surrounding 6 years. This significantly broader screen arguably better manages the concern for contaminated information affecting returns but results in very few IPOs clearing the screen (only 37 withdrawn IPOs from 1980 to 2001).

${ }^{6}$ Other windows around withdrawn IPOs produce qualitatively similar results.
} 
where $\mathrm{R}_{\mathrm{it}}$ is the return event date $\mathrm{t}$ for firm $\mathrm{i}$, and $\mathrm{R}_{\mathrm{mt}}$ is the CRSP value weighted market return on event date t. Abnormal returns for firm $\mathrm{i}$ on date $\mathrm{t}$ around withdrawal, $\mathrm{AR}_{\mathrm{it}}$, are then computed as follows:

$$
A R_{i t}=R_{i t}-\left(\widehat{\alpha_{i}}+\widehat{\beta} R_{m t}\right)
$$

where $\widehat{\alpha_{i}}$ and $\widehat{\beta_{i}}$ are estimated from equation (1). Following Bradley and Yuan (2013) we focus on the cumulative abnormal return $\left(\mathrm{CAR}_{\mathrm{i}}\right)$ for each rival firm $\mathrm{i}$ from days -1 to +1 relative to the withdrawal, calculated as:

$$
C A R_{i}=\sum_{t=-1}^{+1} A R_{i t}
$$

We report average CARs for rival firms of the 220 withdrawn IPOs in the first row of Table 7 (standard errors used to generate t-statistics are based on statistics developed by Boehmer, Musumeci and Poulsen, 1991). ${ }^{7}$ The average three-day reaction by rivals around IPO withdrawal is a statistically significant positive $0.35 \%$, consistent with withdrawals being surprises and creating costs, on average, for issuing firms. This result provides strong support for the explanation that a withdrawal reduces competition both because the firm does not have the IPO proceeds to use, but also because there is one less public firm competing for public market capital and attention.

\section{Insert Table 7 about here}

As reported in the previous section, some withdrawing firms are able to return for a post withdrawal capital market event. In row $2 \mathrm{a}-2 \mathrm{c}$ of Table 7 , we report the market reaction to withdrawals that have (non-bankruptcy) post withdrawal events. There is a significant positive abnormal return for competitors of $0.96 \%$ upon the withdrawal announcement of firms that later attract capital and conduct some other event (e.g., are acquired), again evidencing the assertion that these were viable potential competitors that

\footnotetext{
${ }^{7}$ We consider an alternative approach where we examine the market reaction to portfolios of competitors around withdrawal events. We form value weighted portfolios of the 10 smallest firms in the four-digit SIC code based industry group (smaller firms are more likely to be competitors for withdrawn IPO firms). Event study evidence using this portfolio approach are qualitatively similar to that reported in Table 7 (with similar, though slightly lower, statistical significance given smaller sample sizes).
} 
were unable to complete the IPO which has a positive effect on competitors. These firms are arguably the most viable of the withdrawals, and thus the positive reaction suggests the withdrawal is costly to them.

Row 3 of Table 7 we report the market reaction to the 104 IPO withdrawals from firms not having post withdrawal events. For this sample we find a significantly positive industry average cumulative abnormal return of $0.61 \%$. Again, this is evidence of the effect of a reduction in competition. Further to this, rows $4 \mathrm{a}$ and $5 \mathrm{a}$ show significant positive competitor reactions $(0.95 \%, 1.10 \%)$ to withdrawals that are later able to attract capital greater than 30 days after the IPO. We split the sample at 30 days given the likelihood that markets are aware of near-term ( $<30$ days) alternative capital at the time of the withdrawal, and thus a viable competitor expected to attract public capital is still able to attract capital. As such, we would not expect competitor reaction to the withdrawal (in both rows $4 \mathrm{~b}$ and $5 \mathrm{~b}$ of Table 7 , we see an insignificant abnormal return, suggesting markets had incorporated the near-term capital raise). While rows $4 \mathrm{a} / \mathrm{b}$ include all private placements, rows $5 \mathrm{a} / \mathrm{b}$ include those that occur after the adoption of Rule $155^{8}$ which made it easier for a withdrawing firm to switch to a private offering quickly. The market reactions before and after the Rule change are not statistically different.

The final set of evidence in Table 7 is shown in rows $6 a-6 c$. In row $6 c$ of Table 7 , we see that there is no significant competitor reaction to a withdrawal firm that eventually goes bankrupt. Using the taxonomy of withdrawal types, these are "bad" firms rejected by the markets. The absence of a market reaction is expected given that a well-functioning capital market should reject these firms. However, row $6 \mathrm{~b}$ of Table 7 again provides evidence that when good firms (those that do not eventually go bankrupt) withdraw, competitors have a significant positive abnormal return of $0.35 \%$. Competitor (and their investors) react positively to having a viable competitor fail in its attempt to attract capital and to create an alternative investment opportunity for public market investors.

\footnotetext{
${ }^{8}$ See SEC Release 33-7943. The integration doctrine provides a framework for determining whether multiple securities transactions should be "integrated" into a single transaction. Firms wishing to avoid certain rules might artificially divide an offering into several. Given this, prior to the rule change the SEC required withdrawing firms have a six month cooling off period before switching to private offering (unless the firm relied on another exemption), else risk integrating the offerings and subjecting the firm to cumbersome disclosure and reporting requirements. The rule change reduced the waiting period to 30 days.
} 


\section{Conclusion}

Withdrawal is an important option available to firms pursuing an IPO and that many firms choose to exercise. In this paper we examine two questions. First, what are the post-withdrawal outcomes for firms that do not complete an IPO? While withdrawals are common (35\% of potential issuers in our sample) very little is known about what happens to issuers afterwards. Existing research has only been able to document outcomes for fewer than $30 \%$ of firms that withdraw their IPOs. This study fills a void by carefully following all issuers that withdraw. We document capital market (capital raising or merger/acquisition) and corporate (bankruptcy) events for almost $70 \%$ of firms withdrawing an IPO, while the remaining $30 \%$ simply returned to private status without such capital market or corporate events. We find that approximately $13 \%$ of withdrawn issuers are able to successfully return for an IPO. Approximately $11 \%$ of issuers declare bankruptcy, $36 \%$ are able to raise equity privately and $42 \%$ either merge or are acquired.

After carefully documenting outcomes for withdrawing firms we ask whether withdrawals are costly to issuers. In some cases we are able to identify firm valuations implied both at the time of the initial IPO filing and any post withdrawal capital market (capital raising or merger and acquisition) events. Implied valuations of firms returning for a successful IPO do not change significantly between initial IPO filing and post-withdrawal event. In contrast implied valuations drop significantly between IPO filing and postwithdrawal event for firms pursuing private placements or mergers/acquisitions. This drop in valuation is consistent with withdrawals having a significantly negative impact on firms. It is also consistent with these firms simply setting the initial IPO filing terms too high. To consider this possibility, we identify a matched sample of successful IPOs that significantly cut their issue price (and implied firm valuation) prior to going public. Post-IPO valuation ratios for these issues are more positive than for the sample of withdrawn issuers, indicating that initial overpricing can only partly explain valuation effects.

Given variation in post-withdrawal outcomes and valuation ratios, we examine factors affecting outcomes and valuations. Carter-Manaster ranking for the lead bank in the withdrawn IPO and venture 
capital backing have a significantly positive effect on the likelihood a withdrawing firm has a postwithdrawal capital market outcome (private placement, merger or successful IPO). For issuers having a post-withdrawal corporate event, there is a positive relationship between issuer revenue as well as number of underwriter and valuation ratios. More established firms having the backing of more banks are in a better position to have more positive events (from a valuation perspective) post withdrawal. We also find a negative relationship between valuation ratios and filing size as well as a high tech industry dummy variable. High tech issuers face greater lemons concerns post-withdrawal leading to lower valuations. Issuers that attempt to raise more capital in the IPO also face worse fates (from a valuation perspective) in post withdrawal events. These firms are possibly those that desire to sell as much stock as possible at unduly high prices, although the costs of the costs (real, reputational, or otherwise) incurred in withdrawing harm their future prospects.

While post-withdrawal fates are negative for most firms, it is possible that these are simply 'low quality' firms screened out in the IPO process. To address this possibility, we examine the market reaction to withdrawal by industry rivals. If withdrawals are simply low quality firms being screened by the IPO process, the market reaction to the IPO withdrawal should be negligible. If instead the withdrawal is believed to have hurt a viable competitor, market valuations of publicly traded industry rivals should increase. We find that IPO rival valuations do increase around withdrawals, especially for rivals to the subset of firms either not able to have post-withdrawal capital market outcomes (capital raising or mergers and acquisition) or that have outcomes at discounted valuations. The failure to attract capital, whether in the IPO or otherwise thereafter provides benefits to existing public competitors, suggesting that existing public firms may have an incentive to see competitor IPOs fail.

We conclude with a chronology of issuer decisions informed by this research. An issuer must choose its advisory team and decide when to time its initial IPO filing. During marketing the firm considers its alternatives to a completed IPO and when those alternatives are sufficiently favorable to outweigh the costs of withdrawal (explicit and reputational/lemons) an issuer may withdraw rather than complete the IPO. However, the costs of withdrawal are great, evidenced by the positive market valuation impact of 
existing public rivals - the failure of a credible potential rival to attract capital lowers the competitive threat and existing rivals benefit - suggesting an incentive to see competitors' offerings fail. If a firm is to desire a post-withdrawal outcome, its most sensible tactic is to ensure it has a large number of underwriters, perhaps creating a situation in which the underwriters compete to help the post-withdrawal firm with its alternative outcome. If a firm is to pursue such an alternative, its best path is to re-approach the IPO markets, pursue a merger or acquisition, and finally to pursue a private placement. Finally, while some post-withdrawal options are positive, the costs of withdrawal are substantive and the typical withdrawal firm fares poorly when compared to a matched group that instead chooses to drop their IPO prices substantially and complete their IPOs. This appears to offer a clear message to management as they approach the IPO pricing call toward the end of a road show: complete the IPO, even at a reduced price. 


\section{References}

Akerlof, G., 1970, The market for 'lemons': Quality and the market mechanism, Quarterly Journal of Economics 84, 488-500.

Benveniste, L., Spindt, P., 1989, How investment bankers determine the offer price and allocation of new issues, Journal of Financial Economics 24, 343-362.

Boeh, K., Southam, C., 2011, Impact of initial public offering coalition on deal completion, Venture Capital: An International Journal of Entrepreneurial Finance 13(4), 313-336.

Boehmer, E., Musumeci, J., Poulsen, A., 1991, Event-study Methodology under Conditions of Eventinduced Variance, Journal of Financial Economics, 30, 253-272.

Bradley, D., Jordan, B., 2002, Partial Adjustment to Public Information and IPO Underpricing, Journal of Financial and Quantitative Analysis, 37, 595-616.

Bradley, D., Yuan, X., 2013, Information Spillovers around Seasoned Equity Offerings, Journal of Corporate Finance, 21, 106-118.

Busaba, W., 2006, Bookbuilding, the Option to Withdraw, and the Timing of IPO's, Journal of Corporate Finance 12, 159-186.

Busaba, W., Benveniste, L., Guo, R-J, 2001, The option to withdraw IPOs during the premarket: empirical analysis, Journal of Financial Economics, 60, 73-102.

Carter, R., Manaster, S., 1990, Initial public offerings and underwriter reputation, Journal of Finance 45, 1045-1067.

Carter, R., Dark, F., Singh, A., 1998, Underwriter Reputation, Initial Returns and the Long-Run Performance of IPO Stocks, Journal of Finance 53, 285-312.

Chemmanur, T., Fulghieri, P., 1999, A theory of the going-public decision, Review of Financial Studies 12, 249-279.

Cooney, J., Moeller, T., Stegemoller, M., 2009, The Underpricing of Private Targets, Journal of Financial Economics, 93, 51-66.

Corwin, S., Schulz, P., 2005, The Role of IPO Underwriting Syndicates: Pricing, Information Production, and Aftermarket Liquidity, Journal of Finance 60, 443-486.

Dunbar, C., 1998, The choice between firm-commitment and best-efforts offering methods in IPOs: The effect of unsuccessful offers, Journal of Financial Intermediation 7, 60-90.

Dunbar C., Foerster, S., 2008, Second time lucky? Withdrawn IPOs that return to the market, Journal of Financial Economics 87, 610-635.

Fama, E., French, K., 1997, Industry cost of equity, Journal of Financial Economics 43, 153-193.

Gompers, P., 1996, Grandstanding in the Venture Capital Industry, Journal of Financial Economics 42, 133-156. 
Helwege, J., Liang, N, 2004, Initial Public Offerings in Hot and Cold Markets, Journal of Financial and Quantitative Analysis 39, 541-569.

Hsu, H-C., Reed, A., Rocholl, J., The New Game in Town: Competitive Effects of IPOs, Journal of Finance, 65, 495-528.

Hu, W., Ritter, J., Multiple Bookrunners in IPOs, Unpublished working paper, University of Florida.

Lian, Q., Wang, Q., 2012, Acquisition Valuations of Withdrawn-IPOs: When IPO Plans Turn into Mergers, Unpublished working paper, Louisiana Tech.

Loughran, T., Ritter, J., 2004, Why has IPO initial returns changed over time? Financial Management 33 (3), 5-37.

Murphy, K., Topel, R., 1985, Estimation and Inference in Two-Step Econometric Models, Journal of Business \& Economic Statistics 3, 370-379.

Ritter, J., 1987, The costs of going public, Journal of Financial Economics 19, 269-281.

Welch, I., 1992, Sequential sales, learning and cascades, Journal of Finance 47, 695-732. 


\section{Appendix}

\section{Variable Definitions}

\begin{tabular}{|c|c|c|c|c|c|c|c|c|}
\hline \multirow[b]{2}{*}{ Variable name } & \multirow[b]{2}{*}{ Definition } & \multirow[b]{2}{*}{ Sources of Data } & \multicolumn{2}{|c|}{ Full Sample } & \multicolumn{2}{|c|}{ Successful IPOs } & \multicolumn{2}{|c|}{ Withdrawn IPOs } \\
\hline & & & $\begin{array}{l}\text { Obser- } \\
\text { vations }\end{array}$ & $\begin{array}{c}\text { Mean } \\
\text { (Standard } \\
\text { Deviation) }\end{array}$ & $\begin{array}{l}\text { Obser- } \\
\text { vations }\end{array}$ & $\begin{array}{c}\text { Mean } \\
\text { (Standard } \\
{\text { Deviation })^{+}}\end{array}$ & $\begin{array}{l}\text { Obser- } \\
\text { vations }\end{array}$ & $\begin{array}{c}\text { Mean } \\
\text { (Standard } \\
{\text { Deviation })^{+}}\end{array}$ \\
\hline \multicolumn{9}{|l|}{$\begin{array}{l}\text { Issue } \\
\text { Characteristics }\end{array}$} \\
\hline $\begin{array}{l}\text { Log of Filing } \\
\text { Size }\end{array}$ & $\begin{array}{l}\text { Filing size equals the number of shares to } \\
\text { be sold (primary and secondary), } \\
\text { excluding overallotments in millions } \\
\text { multiplied by the average of the initial } \\
\text { high and low filing price. This variable is } \\
\text { the natural log of filing size }\end{array}$ & $\begin{array}{l}\text { Share and price information from } \\
\text { Thomson Financial Securities } \\
\text { Corporation (TFSDC) Data New } \\
\text { Issues database checked against the } \\
\text { initial IPO prospectus from the SEC's } \\
\text { Edgar database }\end{array}$ & 1660 & $\begin{array}{c}4.153 \\
(0.835)\end{array}$ & 588 & $\begin{array}{c}4.074 \\
(0.768)\end{array}$ & 1072 & $\begin{array}{c}4.196 \\
(0.868)\end{array}$ \\
\hline $\begin{array}{l}\text { Use of } \\
\text { Proceeds to } \\
\text { Repay Debt }\end{array}$ & $\begin{array}{l}\text { Variable equals } 1 \text { if one of the stated use } \\
\text { of proceeds in intial prospectus is to repay } \\
\text { debt }\end{array}$ & $\begin{array}{l}\text { Initial IPO prospectus from the SEC's } \\
\text { Edgar database }\end{array}$ & 1660 & $\begin{array}{c}0.161 \\
(0.368)\end{array}$ & 588 & $\begin{array}{c}0.223 \\
(0.416)\end{array}$ & 1072 & $\begin{array}{c}0.128 \\
(0.334)\end{array}$ \\
\hline \multicolumn{9}{|c|}{ Issuer Characteristics } \\
\hline Log of Revenue & $\begin{array}{l}\text { The last } 12 \text { months revenue (prior to first } \\
\text { filing date) for each IPO issuer in millions } \\
\text { is first obtained. This variable is the } \\
\text { natrual logarithm of } 1 \text { plus revenue }\end{array}$ & $\begin{array}{l}\text { Compustat. Where data is not } \\
\text { available, sales are obtained from the } \\
\text { initial IPO prospectus (Edgar) }\end{array}$ & 1660 & $\begin{array}{c}9.007 \\
(3.059)\end{array}$ & 588 & $\begin{array}{c}8.777 \\
(3.006)\end{array}$ & 1072 & $\begin{array}{c}9.133 \\
(3.081)\end{array}$ \\
\hline $\begin{array}{l}\text { High Tech } \\
\text { Industry } \\
\text { Dummy }\end{array}$ & $\begin{array}{l}\text { Variable equals } 1 \text { if the issuer is in Fama } \\
\text { and French (1997) industries } 35,36 \text { or } 37 \\
\text { (business services, chips, or computers) } \\
\text { based on the SIC code }\end{array}$ & $\begin{array}{l}\text { SIC codes are obtained from TFSDC } \\
\text { Data New Issues database checked } \\
\text { against the initial IPO prospectus from } \\
\text { the SEC's Edgar database }\end{array}$ & 1660 & $\begin{array}{c}0.519 \\
(0.500)\end{array}$ & 588 & $\begin{array}{c}0.515 \\
(0.500)\end{array}$ & 1072 & $\begin{array}{c}0.521 \\
(0.500)\end{array}$ \\
\hline Firm Age & $\begin{array}{l}\text { Firm Age is calendar year of offering } \\
\text { minus calendar year of founding. }\end{array}$ & $\begin{array}{l}\text { Jay Ritter's website } \\
\text { (bear.warrington.ufl.edu/ritter/ipodata.htm) } \\
\text { or initial IPO prospectus from the } \\
\text { SEC's Edgar database }\end{array}$ & 1660 & $\begin{array}{c}8.747 \\
(11.609)\end{array}$ & 588 & $\begin{array}{c}7.807 \\
(8.449)\end{array}$ & 1072 & $\begin{array}{c}9.263 \\
(12.995)\end{array}$ \\
\hline \multicolumn{9}{|c|}{ Intermediary Characteristics } \\
\hline $\begin{array}{l}\text { Carter- } \\
\text { Manaster } \\
\text { Ranking }\end{array}$ & $\begin{array}{l}\text { Ranking (from } 0 \text { to 9.001) is obtained } \\
\text { from Carter and Manaster (1990) as } \\
\text { updated by Carter, Dark and Singh (1998) } \\
\text { and more recently by Loughran and Ritter } \\
\text { (2001). If there are multiple underwriters, } \\
\text { the maximum bank ranking is used. }\end{array}$ & $\begin{array}{l}\text { Jay Ritter's website for Carter- } \\
\text { Manaster rankings. TFSDC New } \\
\text { Issues Database is used to identify } \\
\text { lead underwriters }\end{array}$ & 1660 & $\begin{array}{c}7.909 \\
(1.887)\end{array}$ & 588 & $\begin{array}{c}7.772 \\
(2.050)\end{array}$ & 1072 & $\begin{array}{c}7.984 \\
(1.787)\end{array}$ \\
\hline
\end{tabular}

${ }^{+}$statistic are bolded and italicized when differences between means of successful and withdrawn samples are significantly different using a t-test (at 5\% level or better) 


\section{Appendix}

\section{Variable Definitions, Continued}

\begin{tabular}{|c|c|c|c|c|c|c|c|c|}
\hline \multirow[b]{2}{*}{ Variable name } & \multirow[b]{2}{*}{ Definition } & \multirow[b]{2}{*}{ Sources of Data } & \multicolumn{2}{|c|}{ Full Sample } & \multicolumn{2}{|c|}{ Successful IPOs } & \multicolumn{2}{|c|}{ Withdrawn IPOs } \\
\hline & & & $\begin{array}{l}\text { Obser- } \\
\text { vations }\end{array}$ & $\begin{array}{c}\text { Mean } \\
\text { (Standard } \\
\text { Deviation) } \\
\end{array}$ & $\begin{array}{l}\text { Obser- } \\
\text { vations }\end{array}$ & $\begin{array}{c}\text { Mean } \\
\text { (Standard } \\
{\text { Deviation })^{+}}\end{array}$ & $\begin{array}{l}\text { Obser- } \\
\text { vations }\end{array}$ & $\begin{array}{c}\text { Mean } \\
\text { (Standard } \\
{\text { Deviation })^{+}}\end{array}$ \\
\hline \multicolumn{9}{|c|}{ Intermediary Characteristics (continued) } \\
\hline $\begin{array}{l}\text { Number of } \\
\text { Under-writers }\end{array}$ & $\begin{array}{l}\text { A count of the number of lead underwriters } \\
\text { for the offering }\end{array}$ & $\begin{array}{l}\text { Thomson Financial Securities } \\
\text { Corporation (TFSDC) Data New } \\
\text { Issues database checked against the } \\
\text { initial IPO prospectus (Underwriter } \\
\text { section) from the SEC's Edgar } \\
\text { database }\end{array}$ & 1660 & $\begin{array}{c}3.406 \\
(1.590)\end{array}$ & 588 & $\begin{array}{c}3.020 \\
(1.130)\end{array}$ & 1072 & $\begin{array}{c}3.618 \\
(1.757)\end{array}$ \\
\hline $\begin{array}{l}\text { Venture } \\
\text { Capital } \\
\text { Dummy }\end{array}$ & $\begin{array}{l}\text { A dummy variable equals } 1 \text { if the IPO had } \\
\text { prior venture capital backing and } 0 \\
\text { otherwise }\end{array}$ & $\begin{array}{l}\text { TFSDC New Issues Database is } \\
\text { used to identify presence of } \\
\text { Venture Capital Backing }\end{array}$ & 1660 & $\begin{array}{c}0.646 \\
(0.478)\end{array}$ & 588 & $\begin{array}{c}0.677 \\
(0.468)\end{array}$ & 1072 & $\begin{array}{c}0.630 \\
(0.483)\end{array}$ \\
\hline \multicolumn{9}{|c|}{ Market Conditions - Pre first filing } \\
\hline $\begin{array}{l}\text { Hot IPO } \\
\text { Market } \\
\text { Dummy }\end{array}$ & $\begin{array}{l}\text { Variable equals } 1 \text { if filing takes place in a } \\
\text { month where IPO volume (by number) in } \\
\text { three consecutive months which include this } \\
\text { month fall in top quartile of quarterly } \\
\text { volume over the } 1999-2004 \text { period }\end{array}$ & $\begin{array}{l}\text { IPO issuance dates from TFSDC } \\
\text { New Issues database }\end{array}$ & 1660 & $\begin{array}{c}0.392 \\
(0.488)\end{array}$ & 588 & $\begin{array}{c}0.214 \\
(0.411)\end{array}$ & 1072 & $\begin{array}{c}0.489 \\
(0.500)\end{array}$ \\
\hline $\begin{array}{l}\text { Cold IPO } \\
\text { Market } \\
\text { Dummy }\end{array}$ & $\begin{array}{l}\text { Variable equals } 1 \text { if filing takes place in a } \\
\text { month where IPO volume (by number) in } \\
\text { three consecutive months which include this } \\
\text { month fall in bottom quartile of quarterly } \\
\text { volume over the } 1999-2004 \text { period }\end{array}$ & $\begin{array}{l}\text { IPO issuance dates from TFSDC } \\
\text { New Issues database }\end{array}$ & 1660 & $\begin{array}{c}0.152 \\
(0.359)\end{array}$ & 588 & $\begin{array}{c}0.304 \\
(0.461)\end{array}$ & 1072 & $\begin{array}{c}0.068 \\
(0.252)\end{array}$ \\
\hline \multicolumn{9}{|c|}{ Market Conditions - Post first filing } \\
\hline $\begin{array}{l}\text { Days from } \\
\text { Filing to Offer } \\
\text { or Withdrawal }\end{array}$ & $\begin{array}{l}\text { Number of calendar days from first filing to } \\
\text { either IPO date (if successful) or withdrawal } \\
\text { date (if withdrawn) }\end{array}$ & $\begin{array}{l}\text { Thomson Financial Securities } \\
\text { Corporation (TFSDC) Data New } \\
\text { Issues database checked against } \\
\text { SEC's Edgar database }\end{array}$ & 1660 & $\begin{array}{c}168.269 \\
(166.553)\end{array}$ & 588 & $\begin{array}{l}263.781 \\
(214.590)\end{array}$ & 1072 & $\begin{array}{l}115.881 \\
(99.878)\end{array}$ \\
\hline $\begin{array}{l}\text { Average Daily } \\
\text { Industry } \\
\text { Return From } \\
\text { Filing to IPO } \\
\text { or Withdrawal }\end{array}$ & $\begin{array}{l}\text { The average daily industry (using Fama- } \\
\text { French } 17 \text { industry classification) return } \\
\text { between first pricing and IPO or withdrawal } \\
\text { date }\end{array}$ & $\begin{array}{l}\text { Ken French's website. SIC codes } \\
\text { used to define IPO firm industry } \\
\text { (and issuance dates) are from } \\
\text { TFSDC database with corrections } \\
\text { from Jay Ritter's website and } \\
\text { checked against IPO prospectuses } \\
\text { (from Edgar data base) }\end{array}$ & 1660 & $\begin{array}{c}0.014 \\
(0.167)\end{array}$ & 588 & $\begin{array}{l}-0.059 \\
(0.157)\end{array}$ & 1072 & $\begin{array}{c}0.054 \\
(0.159)\end{array}$ \\
\hline
\end{tabular}

${ }^{+}$statistic are bolded and italicized when differences between means of successful and withdrawn samples are significantly different using a t-test (at 5\% level or better) 


\section{TABLE 1}

\section{Sample Profile: IPO Pipeline, Filings, Completions, Withdrawals}

The table shows the number of IPOs filed, withdrawn (WD), completed and thus, by calculation, the number actively on file ("pipeline") at the beginning of each quarter for the U.S. IPO market from 1999-2004.

\begin{tabular}{|c|c|c|c|c|c|c|c|c|}
\hline \multirow[b]{2}{*}{ Period } & \multirow[b]{2}{*}{$\begin{array}{c}\text { IPO } \\
\text { Pipeline }^{9} \\
\end{array}$} & \multirow[b]{2}{*}{ Filings } & \multirow[b]{2}{*}{ IPOs } & \multirow[b]{2}{*}{ WDs } & \multicolumn{3}{|c|}{ Ratios } & \multirow[b]{2}{*}{$\begin{array}{l}\text { WD \% of } \\
\text { Outcomes }\end{array}$} \\
\hline & & & & & $\begin{array}{l}\text { Filings: } \\
\text { Pipeline } \\
\end{array}$ & $\begin{array}{c}\text { IPOs: } \\
\text { Pipeline } \\
\end{array}$ & $\begin{array}{c}\text { WD: } \\
\text { Pipeline }\end{array}$ & \\
\hline Q1 & 141 & 107 & 51 & 29 & $.76 x$ & $.36 \mathrm{x}$ & $.21 \mathrm{x}$ & $36 \%$ \\
\hline Q2 & 168 & 170 & 120 & 32 & $1.01 \mathrm{x}$ & $.71 x$ & $.19 \mathrm{x}$ & 21 \\
\hline Q3 & 186 & 160 & 117 & 25 & $.86 x$ & $.63 x$ & $.13 x$ & 18 \\
\hline Q4 & 204 & 113 & 129 & 29 & $.55 x$ & $.63 x$ & $.14 \mathrm{x}$ & 18 \\
\hline 1999 & Sub-total & 550 & 417 & 115 & & & & $22 \%$ \\
\hline Q1 & 159 & 240 & 99 & 20 & $1.51 \mathrm{x}$ & $.62 x$ & $.13 x$ & $17 \%$ \\
\hline Q2 & 280 & 162 & 70 & 70 & $.58 x$ & $.25 x$ & $.25 \mathrm{x}$ & 50 \\
\hline Q3 & 302 & 95 & 105 & 48 & $.31 x$ & $.35 x$ & $.16 \mathrm{x}$ & 31 \\
\hline Q4 & 244 & 46 & 34 & 86 & $.19 x$ & $.14 \mathrm{x}$ & $.35 \mathrm{x}$ & 72 \\
\hline 2000 & Sub-total & 543 & 308 & 224 & & & & $42 \%$ \\
\hline Q1 & 170 & 20 & 13 & 70 & $.12 \mathrm{x}$ & $.08 x$ & $.41 x$ & $84 \%$ \\
\hline Q2 & 107 & 13 & 18 & 32 & $.12 \mathrm{x}$ & $.17 \mathrm{x}$ & $.30 \mathrm{x}$ & 64 \\
\hline Q3 & 70 & 24 & 6 & 21 & $.34 x$ & $.09 x$ & $.30 \mathrm{x}$ & 78 \\
\hline Q4 & 67 & 16 & 21 & 15 & $.24 \mathrm{x}$ & $.31 x$ & $.22 \mathrm{x}$ & 42 \\
\hline 2001 & Sub-total & 73 & 58 & 138 & & & & $70 \%$ \\
\hline Q1 & 47 & 33 & 9 & 6 & $.70 x$ & $.19 \mathrm{x}$ & $.13 x$ & $40 \%$ \\
\hline Q2 & 65 & 40 & 29 & 4 & $.62 x$ & $.45 x$ & $.06 \mathrm{x}$ & 12 \\
\hline Q3 & 72 & 15 & 4 & 13 & $.21 \mathrm{x}$ & $.06 \mathrm{x}$ & $.18 x$ & 76 \\
\hline Q4 & 70 & 10 & 18 & 17 & $.14 \mathrm{x}$ & $.26 \mathrm{x}$ & $.24 \mathrm{x}$ & 49 \\
\hline 2002 & Sub-total & 98 & 60 & 40 & & & & $40 \%$ \\
\hline Q1 & 45 & 4 & 2 & 19 & $.09 \mathrm{x}$ & $.04 x$ & $.42 x$ & $90 \%$ \\
\hline Q2 & 28 & 8 & 3 & 7 & $.29 x$ & $.11 \mathrm{x}$ & $.25 \mathrm{x}$ & 70 \\
\hline Q3 & 26 & 43 & 16 & 4 & $1.65 x$ & $.62 x$ & $.15 \mathrm{x}$ & 20 \\
\hline Q4 & 49 & 35 & 41 & 3 & $.71 x$ & $.84 x$ & $.06 x$ & 7 \\
\hline 2003 & Sub-total & 90 & 62 & 33 & & & & $35 \%$ \\
\hline Q1 & 40 & 64 & 29 & 1 & $1.60 x$ & $.73 x$ & $.03 x$ & $3 \%$ \\
\hline Q2 & 74 & 70 & 43 & 7 & $.95 x$ & $.58 \mathrm{x}$ & $.09 \mathrm{x}$ & 14 \\
\hline Q3 & 94 & 42 & 43 & 15 & $.45 x$ & $.46 x$ & $.16 \mathrm{x}$ & 26 \\
\hline Q4 & 78 & 50 & 52 & 15 & $.64 x$ & $.67 x$ & $.19 \mathrm{x}$ & 22 \\
\hline 2004 & Sub-total & 226 & 167 & 38 & & & & $19 \%$ \\
\hline $\begin{array}{l}\text { Totals } \\
\text { Means }\end{array}$ & & 1580 & 1072 & 588 & $.61 x$ & $.39 x$ & $.20 x$ & $35 \%$ \\
\hline
\end{tabular}

\footnotetext{
${ }^{9}$ Pipeline figure are "beginning" of quarter deals on file. As such, 2004 ends with 61 (=78+50-52-15).
} 


\section{TABLE 2}

\section{IPO Withdrawal Reasons Filed with the SEC, 1999-2004}

The table categorizes the stated reasons for the withdrawal of IPOs from registration with the U.S. SEC. Securities regulations require that an issuer state a reason for withdrawing (and thus not completing) its initial public offering on a form RW that is filed with the SEC. The data were collected for every (588) offering withdrawn from 1999 2004. Data were obtained from S.E.C. form RW filings.

\begin{tabular}{|c|c|c|c|}
\hline Category & Stated Reason for Withdrawal & Number & Percent \\
\hline \multicolumn{4}{|c|}{ Informative - Volitional } \\
\hline & Change - Business plans & 6 & $1.02 \%$ \\
\hline & Change - Management or Underwriter & 4 & $.68 \%$ \\
\hline & Discretionary financing & 14 & $2.38 \%$ \\
\hline & Merger/Acquisition - Related & 46 & $7.82 \%$ \\
\hline & No longer intends to sell & 19 & $3.23 \%$ \\
\hline & Plan to re-file a new prospectus & 2 & $.34 \%$ \\
\hline & Switch to private offering & 3 & $.51 \%$ \\
\hline & & 94 & $15.98 \%$ \\
\hline \multicolumn{4}{|c|}{ Informative - Negative } \\
\hline & Bankruptcy/ran out of money & 2 & $.34 \%$ \\
\hline & Regulatory/accounting concerns & 2 & $.34 \%$ \\
\hline & Underwriter - Could not complete & 3 & $.51 \%$ \\
\hline & Underwriter - Withdrew & 2 & $.34 \%$ \\
\hline & Marketability question & 2 & $.34 \%$ \\
\hline & Terms not acceptable & 8 & $1.36 \%$ \\
\hline & Not in best interest of investors & 23 & $3.91 \%$ \\
\hline & Public interest/protection of investors & 9 & $1.53 \%$ \\
\hline & & 51 & $8.67 \%$ \\
\hline \multicolumn{4}{|l|}{ Uninformative } \\
\hline & Market conditions & 318 & $54.08 \%$ \\
\hline & No reason cited & 31 & $5.27 \%$ \\
\hline & Timing & 15 & $2.55 \%$ \\
\hline & & 364 & $61.90 \%$ \\
\hline \multicolumn{4}{|c|}{ Compliance-related } \\
\hline & Withdrawal request not filed with SEC & 79 & $13.44 \%$ \\
\hline & Total & 588 & $100 \%$ \\
\hline
\end{tabular}




\section{TABLE 3}

\section{Actual Outcomes of all IPOs Withdrawn from 1999-2004}

The table records outcome events that occurred in the four years following the withdrawal of every (588) IPO withdrawn from registration with the U.S. SEC. Withdrawn offerings include all intended issuers that withdrew their issues from SEC registration from 1999 - 2004. Events that may have occurred after withdrawal include the completion of a private placement, the re-filing for an IPO, a bankruptcy filing, and the merger or sale of an intended issuer. Events data were obtained from SEC filings (including REGDEX filings), press releases, court records, and Thomson Financials SDC database.

\begin{tabular}{|c|c|c|c|c|c|c|}
\hline \multirow[b]{2}{*}{ Outcome Description } & \multicolumn{4}{|c|}{ Event } & \multirow[b]{2}{*}{ Count } & \multirow[b]{2}{*}{ Percent } \\
\hline & $\begin{array}{c}\text { Private } \\
\text { Placement }\end{array}$ & $\begin{array}{l}\text { Re-file } \\
\text { IPO }\end{array}$ & $\begin{array}{l}\text { Bank- } \\
\text { ruptcy }\end{array}$ & $\begin{array}{c}\text { Merger } \\
\text { or Sale }\end{array}$ & & \\
\hline Return to private status & & & & & 180 & $30.61 \%$ \\
\hline Switch to private placement & $\sqrt{ }$ & & & & 74 & $12.59 \%$ \\
\hline Try IPO again & & $\checkmark$ & & & 20 & $3.40 \%$ \\
\hline IPO was the last hope & & & $\sqrt{ }$ & & 20 & $3.40 \%$ \\
\hline Switch to merger or acquisition & & & & $\checkmark$ & 122 & $20.75 \%$ \\
\hline Raise private then re-file & $\checkmark$ & $\checkmark$ & & & 29 & $4.93 \%$ \\
\hline Raise private then fail & $\checkmark$ & & $\checkmark$ & & 12 & $2.04 \%$ \\
\hline Raise private then sell & $\checkmark$ & & & $\checkmark$ & 81 & $13.78 \%$ \\
\hline Re-file, but too late & & $\checkmark$ & $\checkmark$ & & 2 & $.34 \%$ \\
\hline Re-file, sell instead & & $\checkmark$ & & $\checkmark$ & 7 & $1.19 \%$ \\
\hline Bankrupt, desperation sale & & & $\checkmark$ & $\checkmark$ & 19 & $3.23 \%$ \\
\hline $\begin{array}{l}\text { Raise private, re-file, too little, too } \\
\text { late }\end{array}$ & $\checkmark$ & $\checkmark$ & $\checkmark$ & & 7 & $1.19 \%$ \\
\hline Raise private, re-file, sell instead & $\checkmark$ & $\checkmark$ & & $\checkmark$ & 9 & $1.53 \%$ \\
\hline $\begin{array}{l}\text { Re-file, bankruptcy, desperation } \\
\text { sale }\end{array}$ & & $\checkmark$ & $\checkmark$ & $\checkmark$ & 3 & $.51 \%$ \\
\hline $\begin{array}{l}\text { Raise private, re-file, bankruptcy, } \\
\text { sale }\end{array}$ & $\checkmark$ & $\checkmark$ & $\checkmark$ & $\checkmark$ & 3 & $.51 \%$ \\
\hline Count & 215 & 74 & 66 & 250 & 588 & \\
\hline Percent of withdrawals & $36.56 \%$ & $12.59 \%$ & $11.22 \%$ & $42.52 \%$ & & \\
\hline
\end{tabular}




\section{Table 4}

\section{Valuation of Post-IPO Withdrawal Outcomes}

This table compares the implied valuation of an issuer broken down by capital market outcome for every withdrawn IPO from 1999 to 2004 . Implied valuation at initial IPO filing is the number of shares to be outstanding after the IPO times the IPO filing price (average of high and low filing price). Implied valuation at time of a post-withdrawal private placement is defined similarly (share price in private placement multiplied by share to be outstanding after the private placement). Implied Valuation at the time of a post-withdrawal merger or acquisition is the firm value (market capitalization) implied by the merger or acquisition terms. Implied Valuation at the time of a post-withdrawal successful IPO refiling is the number of shares to be outstanding after the IPO refiling times the IPO refiling price (average of high and low filing price). All implied valuations are reported in millions of dollars. Valuation ratio is the implied valuation implied in the post-withdrawal outcome divided by the implied valuation at the time of the original IPO filing scaled up by the cumulative return on the issuers industry (using the Fama-French 17 industry classification from Ken French's website) between the original IPO filing date and post-withdrawal event announcement. The final column reports the maximum valuation ratio from withdrawal to any post-withdrawal capital market outcome (in many cases a firm has more than one outcome). The $\mathrm{t}$-statistic for valuation ratios is for the test of whether the mean valuation ratio equals 1 . The $\mathrm{z}$-statistic for valuation ratios is for the test of whether the proportion of valuation ratios above 1 equals 0.5 .

\section{Implied Valuations}

Valuation Ratios

$\begin{array}{cccc}\text { Initial IPO } & \text { Post- } & \text { Post- } & \text { Post- } \\ \text { Filing } & \text { withdrawal } & \text { Withdrawal } & \text { withdrawal } \\ & \text { Private } & \text { Merger or } & \text { IPO refiling } \\ & \text { Placement } & \text { Acquisition } & \end{array}$

$\begin{array}{cc}\text { Private } & \text { Merger/ } \\ \text { Placement } & \text { Acquisition } \\ \text { to } & \text { to } \\ \text { Withdrawn } & \text { Withdrawn } \\ \text { IPO } & \text { IPO }\end{array}$
Refiled IPO Best capital
to market
Withdrawn outcome
IPO to
to
IPO

\begin{tabular}{|c|c|c|c|c|c|c|c|c|}
\hline Number with values & 314 & 89 & 148 & 45 & 47 & 68 & 22 & 113 \\
\hline Total sample size & 588 & 212 & 234 & 45 & 212 & 234 & 45 & 368 \\
\hline Rate of disclosure & $53 \%$ & $42 \%$ & $63 \%$ & $100 \%$ & $22 \%$ & $29 \%$ & $49 \%$ & $31 \%$ \\
\hline Mean value & 309.00 & 198.78 & 333.20 & 518.72 & $0.515 x$ & $0.810 \mathrm{x}$ & $1.223 \mathrm{x}$ & $0.776 x$ \\
\hline Standard deviation & 338.87 & 302.88 & 781.93 & 1349.80 & 0.374 & 0.790 & 0.814 & 0.729 \\
\hline t-statistic & & & & & -8.88 & -1.99 & 1.29 & -3.26 \\
\hline Median value & 229.22 & 126.54 & 133.65 & 247.89 & 0.395 & 0.667 & 0.993 & 0.615 \\
\hline Proportion above 1 & & & & & 0.085 & 0.324 & 0.455 & 0.248 \\
\hline z-statistic & & & & & -10.19 & -3.11 & -0.43 & -6.21 \\
\hline
\end{tabular}




\section{Table 5}

\section{Valuation Ratios for IPOs (1990-2004) with Price Adjustments <-20\%}

This table reports valuation ratios for successful IPOs from 1999 to 2004 where the price adjustment for the IPO is less that $-20 \%$. Price adjustment is defined as the IPO price divided by the average of the initial high and low filing price (noted on either the initial IPO filing or an early amendment). To determine the valuation ratio for each IPO company we first compute the ratio of the market capitalization (price per share times number of shares outstanding) at the date firm delists or is acquired or its fifth year anniversary of initial trading, whichever comes first, to the market capitalization based on initial filing terms. We then compute the cumulative return on the issuers industry (using the FamaFrench 17 industry classification from Ken French's website) over the same period. The valuation ratio is 1 plus the firm's market capitalization ratio divided by one plus the industry return. The t-statistic for valuation ratios is for the test of whether the mean valuation ratio equals 1 . The $\mathrm{z}$-statistic for valuation ratios is for the test of whether the proportion of valuation ratios above 1 equals 0.5 .

\begin{tabular}{lcccc}
\hline & All IPOs & $\begin{array}{c}\text { IPOs that } \\
\text { are acquired }\end{array}$ & $\begin{array}{c}\text { IPOs that } \\
\text { are delisted }\end{array}$ & $\begin{array}{c}\text { IPOs that } \\
\text { are not } \\
\text { delisted }\end{array}$ \\
\hline Mean value & $1.140 \mathrm{x}$ & $1.005 \mathrm{x}$ & $0.051 \mathrm{x}$ & $1.325 \mathrm{x}$ \\
Standard deviation & 1.660 & 1.232 & 0.157 & 1.727 \\
t-statistic & 1.19 & 0.03 & -32.55 & 2.46 \\
& & & & 0.703 \\
Median value & 0.495 & 0.660 & 0.019 & $41.5 \%$ \\
Proportion above 1 & $35.5 \%$ & $38.5 \%$ & $0.0 \%$ & -2.25 \\
Z-statistic & -4.29 & -1.71 & - & 171 \\
& & & 29 & \\
\hline
\end{tabular}




\section{Table 6}

\section{Determinants of Post -IPO Withdrawal Outcomes}

This table reports Probit regressions for different post-withdrawal outcomes. In model 1, the dependent variable equals 1 if the withdrawing firm has a private placement or is involved in a merger/acquisition or successfully returns for an IPO within five years of the initial filing. In model 2 , the dependent variable takes the value 1 if the valuation ratio is greater or equal to one. To define the valuation ratio we first compute the valuation implied from each post withdrawal event within five years of the IPO filing where valuation terms (market capitalization) are revealed. This is divided by the valuation implied by the initial IPO filing, scaled up by the cumulative return on the issuers industry (using the Fama-French 17 industry classification from Ken French's website; SIC codes used to defined industry are from the TFSD database with corrections from Jay Ritter's website). The valuation ratio (dependent variable) is the maximum value across post withdrawal events. All independent variables are defined in Appendix 1. Marginal effect is defined as $\phi(\beta * x) * \beta^{*} \sigma$ where $\phi()$ is the standard normal probability density function, $\beta$ is the coefficient estimate, $\mathrm{x}$ is the mean of the independent variable for the sample, and $\sigma$ is one standard deviation for the independent variable ( $\sigma$ is set to 1 for dummy variables). Pseudo $\mathrm{R}^{2}$ is defined as 1 less the log likelihood for the estimated model divided by the log-likelihood for a model with only an intercept as an independent variable. Significant variables (at the $5 \%$ level or better) are bolded and italicized (t-statistics are reported in parentheses)

Constant

\section{Issue Characteristics}

Log of Filing Size

Use of Proceeds to Repay Debt

\section{Issuer Characteristics}

Log of Revenue

High Tech Industry Dummy

Firm Age

\section{Intermediary Characteristics}

Carter-Manaster Ranking

Number of Underwriters

Venture Capital Dummy

Market Conditions - Pre first filing

Hot IPO Market Dummy

Cold IPO Market Dummy

Market Conditions - Post first filing

Days from Filing to Offer or Withdrawal

Average Daily Industry Return From Filing to IPO or Withdrawal

Pseudo- $\mathrm{R}^{2}$

observations

\section{(1)}

Private Placement or M\&A or successful IPO refiling

Coeff-

icient

(2)

\section{Valuation Ratio}

\begin{tabular}{cccccc}
\multicolumn{2}{c}{ or successful IPO refiling } & & & \\
$\begin{array}{c}\text { Coeff- } \\
\text { icient }\end{array}$ & $\begin{array}{c}\text { Marginal } \\
\text { Effect }\end{array}$ & $\begin{array}{c}\mathrm{t}- \\
\text { statistic }\end{array}$ & $\begin{array}{c}\text { Coeff- } \\
\text { icient }\end{array}$ & $\begin{array}{c}\text { Marginal } \\
\text { Effect }\end{array}$ & $\begin{array}{c}\mathrm{t}- \\
\text { statistic }\end{array}$ \\
\hline-0.614 & -0.196 & $(-1.81)$ & -0.840 & -0.287 & $(-0.74)$ \\
-0.094 & -0.027 & $(-0.91)$ & $\mathbf{- 0 . 7 7 7}$ & $\mathbf{- 0 . 1 7 5}$ & $\mathbf{( - 2 . 1 3 )}$ \\
-0.080 & -0.013 & $(-0.57)$ & -0.482 & -0.065 & $(-1.20)$ \\
& & & & & \\
-0.027 & -0.031 & $(-1.29)$ & $\mathbf{0 . 1 9 4}$ & $\mathbf{0 . 1 6 2}$ & $\mathbf{( 2 . 6 7 )}$ \\
0.075 & 0.014 & $(0.65)$ & $\mathbf{- 0 . 7 3 7}$ & $\mathbf{- 0 . 1 2 7}$ & $\mathbf{( - 2 . 3 8 )}$ \\
-0.001 & -0.004 & $(-0.18)$ & -0.026 & -0.072 & $(-1.43)$ \\
& & & & & \\
$\mathbf{0 . 1 0 8}$ & $\mathbf{0 . 0 8 3}$ & $(2.57)$ & 0.054 & 0.030 & $(0.39)$ \\
0.099 & 0.042 & $(1.60)$ & $\mathbf{0 . 3 9 9}$ & $\mathbf{0 . 1 5 4}$ & $\mathbf{( 2 . 2 9 )}$ \\
$\mathbf{0 . 6 3 0}$ & $\mathbf{0 . 2 4 1}$ & $\mathbf{( 4 . 7 5 )}$ & 0.533 & 0.167 & $(1.39)$ \\
& & & & & \\
0.044 & 0.016 & $(0.28)$ & 0.180 & 0.063 & $(0.44)$ \\
0.029 & 0.011 & $(0.20)$ & 0.501 & 0.178 & $(1.38)$ \\
0.000 & 0.000 & $(-0.12)$ & 0.001 & 0.000 & $(1.11)$ \\
0.022 & 0.008 & $(0.05)$ & 1.218 & 0.417 & $(1.02)$ \\
& 0.103 & & & 0.158 & \\
& 588 & & & 113 & \\
& & & & &
\end{tabular}




\section{Table 7}

\section{Market Reaction to Announcement of IPO Withdrawal for Rivals}

This table presents average cumulative abnormal returns (CARs) across event windows from day -1 to day +1 around withdrawal of IPOs for industry rival firms. We only consider withdrawn IPOs where there are no other four-digit SIC code based industry IPOs filed within 4 months of the withdrawal date and no industry IPOs completed in the subsequent four months. Withdrawn IPOs are then grouped based on post withdrawal outcomes ("post withdrawal events" include mergers, private placements or successful IPOs). For each withdrawn IPO we identify CARs for all publicly traded firms in the same four-digit SIC code industry who have traded for at least one year. The market model with returns from trading day -250 to trading day -11 is used to estimate CARs. Boehmer, Musumeci and Poulsen (1991) t-statistics are provided in parentheses.

\begin{tabular}{|c|c|c|}
\hline & Observations & $\begin{array}{r}\text { CAR } \\
(-1,+1) \\
\end{array}$ \\
\hline (1) All withdrawn firms & 5125 & $\begin{array}{r}0.35 \% \\
(2.24)\end{array}$ \\
\hline (2a) Firm only has private placement post withdrawal & 626 & $\begin{array}{r}-0.20 \% \\
(-0.49)\end{array}$ \\
\hline (2b) Firm has a non-private placement post-withdrawal event & 1510 & $\begin{array}{r}-0.17 \% \\
(-0.63)\end{array}$ \\
\hline (2c) Firm has a private placement plus some other post-withdrawal event & 1008 & $\begin{array}{r}0.96 \% \\
(2.47)\end{array}$ \\
\hline (3) Firm has no post-withdrawal event & 1981 & $\begin{array}{r}0.61 \% \\
(2.45)\end{array}$ \\
\hline (4a) Firm has private placement $>30$ days post withdrawal & 1109 & $\begin{array}{r}0.95 \% \\
(2.92)\end{array}$ \\
\hline (4b) Firm has private placement $<30$ days post withdrawal & 525 & $\begin{array}{r}-0.39 \% \\
(-0.69)\end{array}$ \\
\hline (4c) Difference in means between samples & & $\begin{array}{r}-1.34 \% \\
(-2.34)\end{array}$ \\
\hline (5a) Firm has private placement $>30$ days post withdrawal post 20010126 & 639 & $\begin{array}{r}1.10 \% \\
(2.58)\end{array}$ \\
\hline (5b) Firm has private placement $<30$ days post withdrawal post 20010126 & 238 & $\begin{array}{l}1.04 \% \\
(1.06)\end{array}$ \\
\hline (5c) Difference in means between samples & & $\begin{array}{r}-0.07 \% \\
(-0.08)\end{array}$ \\
\hline (6a) Withdrawn firm goes bankrupt post withdrawal & 622 & $\begin{array}{r}0.32 \% \\
(0.71)\end{array}$ \\
\hline (6b) Withdrawn firm does not go bankrupt post withdrawal & 4503 & $\begin{array}{r}0.35 \% \\
(2.13)\end{array}$ \\
\hline (6c) Difference in means between samples & & $\begin{array}{c}0.03 \% \\
(0.05)\end{array}$ \\
\hline
\end{tabular}


FIGURE 1

A Taxonomy of Withdrawal Theories

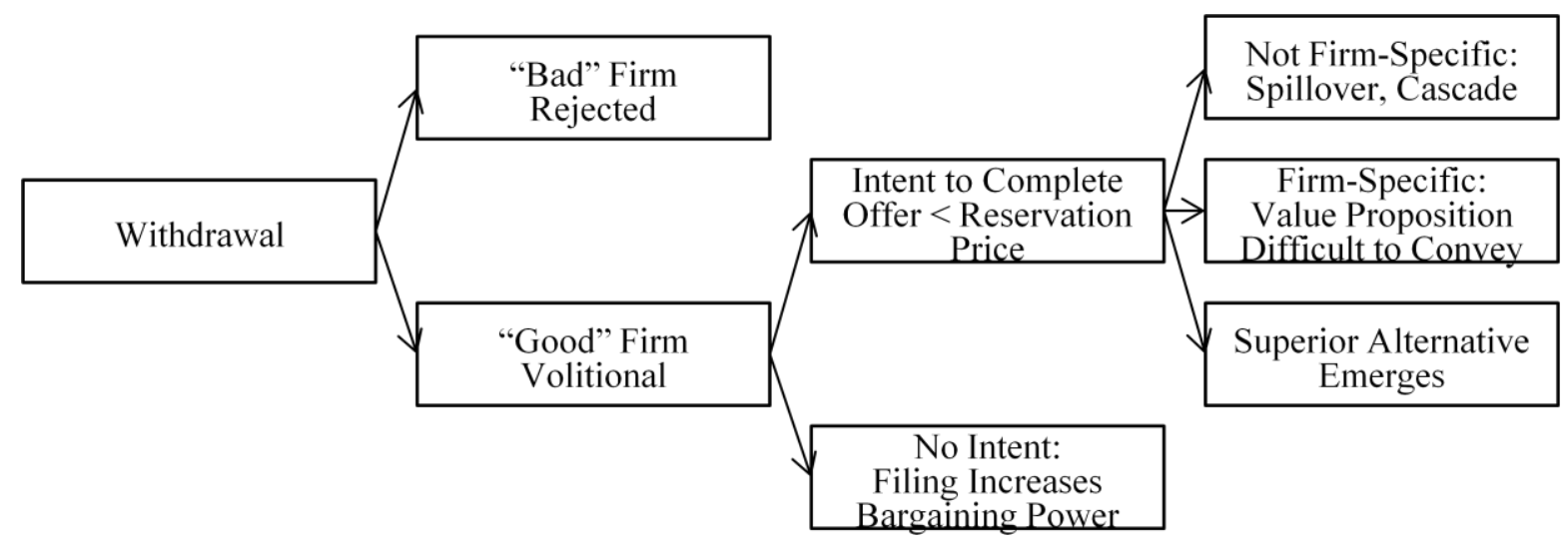

